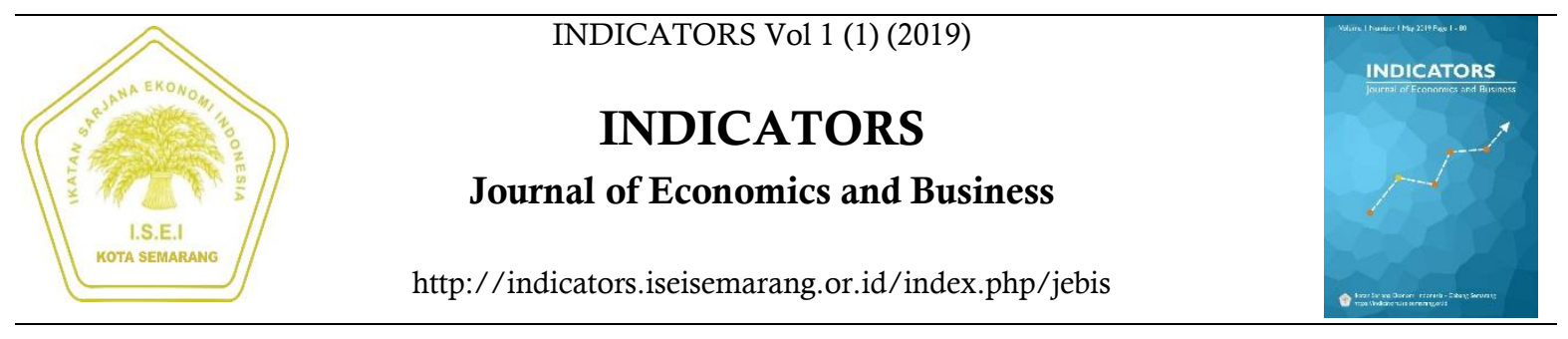

\title{
Analisis Ricardian Equivalence Hypothesis di Indonesia: Pengaruh Kebijakan Fiskal terhadap Konsumsi Masyarakat
}

Bekti Ayu Selawati ${ }^{1 \bowtie}$, Evi Yulia Purwanti²

Universitas Diponegoro

\begin{tabular}{|c|c|}
\hline Info Artikel & Abstrak \\
\hline $\begin{array}{l}\text { Keywords: } \\
\text { Consumption, error } \\
\text { correction model, fiscal } \\
\text { policy, keynesian, ricardian } \\
\text { equivalence hypothesis }\end{array}$ & $\begin{array}{l}\text { Belanja pemerintah pusat cenderung mengalami peningkatan dari tahun ke tahun. Jumlah } \\
\text { penerimaan pajak yang lebih kecil daripada kebutuhan belanja mendorong pemerintah untuk } \\
\text { memperoleh sumber pembiayaan, yang salah satunya dengan melakukan penarikan utang luar } \\
\text { negeri. Beban utang luar negeri yang semakin tahun semakin meningkat bisa mempengaruhi } \\
\text { perekonomian Indonesia. Penelitian ini bertujuan untuk menganalisis pengaruh kebijakan fiskal dan } \\
\text { utang luar negeri pemerintah terhadap konsumsi masyarakat. Penelitian ini juga menggunakan } \\
\text { Produk Domestik Bruto (PDB) dan kekayaan sebagai faktor yang mempengaruhi konsumsi. Data } \\
\text { yang digunakan di dalam penelitian merupakan data sekunder yang diperoleh dari Kementerian } \\
\text { Keuangan, Badan Pusat Statistik dan World Bank tahun } 1973 \text { sampai dengan } 2014 \text {. Metode analisis } \\
\text { yang digunakan adalah Error Correction Model (ECM). Hasil penelitian menunjukkan bahwa } \\
\text { variabel kebijakan fiskal melalui instrumen belanja pemerintah pusat dan pembayaran bunga utang } \\
\text { tidak signifikan mempengaruhi konsumsi dalam jangka pendek. Namun dalam panjang, seluruh } \\
\text { variabel independen yang digunakan di dalam penelitian terbukti secara statistik berpengaruh } \\
\text { signifikan terhadap konsumsi masyarakat. Ricardian Equivalence Hypothesis tentang adanya } \\
\text { netralitas kebijakan fiskal tidak berlaku di dalam perekonomian Indonesia untuk periode } 1973 \\
\text { hingga } 2014 \text {. }\end{array}$ \\
\hline
\end{tabular}

Abstract

Central government spending tends to increase year to year. The amount of tax revenue that is less than the expenditure encourages the government to obtain financing sources, one of which is the withdrawal of foreign debt. The foreign debt burden that is increasingly growing could affect Indonesian economy. The aim of this study was to analyze the effects of fiscal policy and government foreign debt on consumption. This study also uses Gross Domestic Product (GDP) and wealth as factors affecting consumption. Data used in this study are secondary data obtained from Ministry of Finance, Statistics Indonesia and World Bank from 1973 to 2014. The analytical method used is the Error Correction Model (ECM). The results showed that the fiscal policy variable through instrument of central government spending and interest payment on debt does not significantly affect consumption in the short-term. However, in the long-term, all independent variables used in this study showed a statistically significant effect on consumption. Ricardian Equivalence Hypothesis about the neutrality of fiscal policy does not apply in the Indonesian economy for period 1973 to 2014.

\footnotetext{
${ }^{\triangle}$ Alamat korespondensi:

Jl. Erlangga Tengah No.17, Semarang, 50229

E-mail: bektiayu07@gmail.com
} 


\section{PENDAHULUAN}

Pertumbuhan ekonomi Indonesia mengalami penurunan beberapa tahun terakhir. Berdasarkan data yang diperoleh dari World Bank, pertumbuhan ekonomi Indonesia berada pada level $6,2 \%$ pada tahun 2010 , namun menurun menjadi 5,0\% di tahun 2014. Penurunan tingkat pertumbuhan ekonomi ini mengindikasikan semakin lesunya perekonomian Indonesia. Posisi pertumbuhan ekonomi Indonesia di kawasan ASEAN (Association of Southeast Asian Nations) tahun 2014 berada di peringkat tujuh, lebih rendah dari Myanmar, Laos, Kamboja, Filipina, Malaysia dan Vietnam.

Pemerintah perlu melakukan upaya untuk menggerakkan perekonomian Indonesia, di mana peran pemerintah dapat dilakukan melalui kebijakan fiskal, baik melalui pengaturan perpajakan maupun pengaturan terhadap pengeluaran pemerintah. Kebijakan pengeluaran pemerintah akan mampu mendorong pertumbuhan ekonomi apabila digunakan untuk kegiatan produktif (Kementerian Keuangan, 2011).

Kebijakan fiskal di Indonesia tercermin dalam Anggaran Pendapatan dan Belanja Negara (APBN). Data APBN menunjukkan bahwa besarnya pengeluaran/belanja pemerintah tahun 2010 - 2014 selalu mengalami peningkatan. Hingga tahun 2014, belanja pemerintah telah mencapai 1.203.577,17 miliar rupiah, sebesar $12,24 \%$ digunakan untuk belanja modal, sedangkan $87,76 \%$ didominasi oleh belanja operasi yang digunakan untuk kegiatan sehari-hari pemerintah dan memberi manfaat jangka pendek.

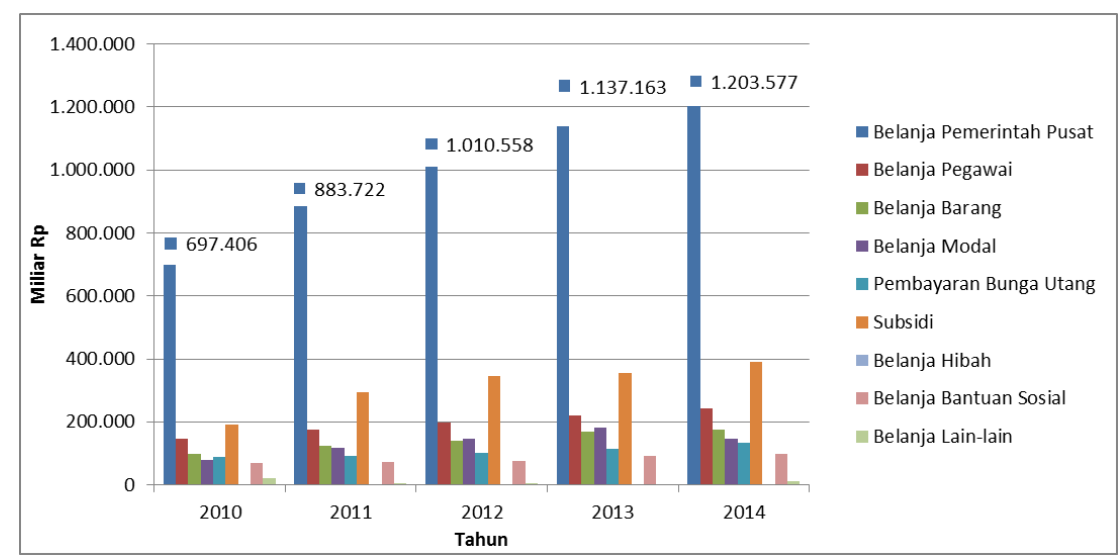

Grafik 1. Perkembangan dan Komposisi Belanja Pemerintah Pusat dalam APBN

Tahun 2010 - 2014

Sumber: Laporan Keuangan Pemerintah Pusat Tahun 2010 - 2014, diolah

Kebutuhan belanja pemerintah yang selalu meningkat berdampak pada semakin tingginya kebutuhan atas sumber-sumber penerimaan. Kebijakan anggaran defisit yang diterapkan pemerintah menunjukkan bahwa penerimaan pajak lebih kecil daripada belanja pemerintah, atau dengan kata lain, penerimaan yang diperoleh dari pajak tidak mencukupi untuk membiayai kebutuhan belanja pemerintah. Pada tahun 2014, penerimaan pajak sebesar 1.146.865,77 miliar rupiah, lebih rendah dibandingkan kebutuhan belanja pemerintah yang mencapai 1.203.577,17 miliar rupiah. Konsekuensinya, pemerintah harus memperoleh sumber pembiayaan (baik dari dalam maupun luar negeri) untuk membiayai defisit anggaran pada tahun yang bersangkutan.

Utang luar negeri merupakan sumber pembiayaan defisit yang dapat diandalkan oleh pemerintah, yang jumlahnya cenderung mengalami peningkatan dari tahun ke tahun. Hingga tahun 2014, posisi utang luar negeri pemerintah telah mencapai 143.068 juta USD, meningkat $10,69 \%$ dari tahun sebelumnya. 


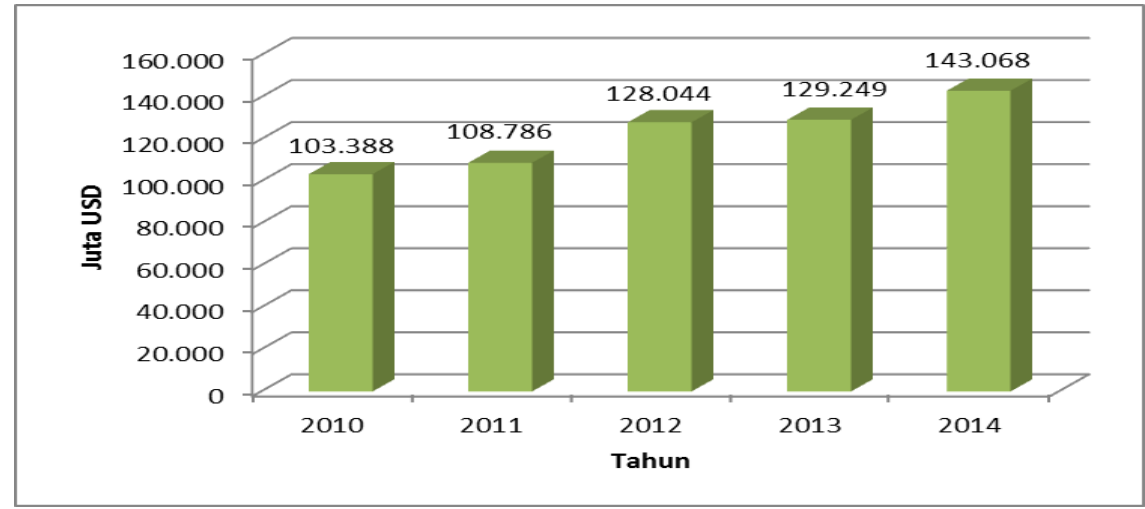

Grafik 2. Perkembangan Utang Luar Negeri Pemerintah (PPG*)

Tahun 2010 - 2014

* External Debt Stock, Public and Publicly Guaranteed

Sumber: World Bank, diolah

Utang luar negeri berdampak pada perekonomian suatu negara, bisa berupa dampak positif maupun dampak negatif tergantung dari sudut pandang terhadap utang itu sendiri. Utang yang digunakan untuk membiayai kegiatankegiatan produktif akan mampu mendorong peningkatan kegiatan ekonomi, sehingga berdampak pada peningkatan pertumbuhan ekonomi. Namun di sisi lain, utang yang semakin tinggi sebagai pengaruh pembangunan neo liberal sejak awal orde baru hingga saat ini semakin membebani masyarakat luas (Arif dan Sasono serta Rachbini dalam Hakim, 2006). Utang merupakan sumber pembiayaan bagi pemerintah untuk membiayai pembangunan, namun jumlah utang yang semakin besar merupakan beban bagi masyarakat di masa mendatang.

Ricardian Equivalence Hypothesis (REH) merupakan salah satu studi yang mempelajari bagaimana dampak utang pemerintah terhadap perekonomian. Hipotesis ini dikemukakan oleh Barro (1974), mengelaborasikan pemikiran ekonom klasik David Ricardo di mana utang pemerintah pada masa ini akan menyebabkan peningkatan beban masyarakat di masa yang akan datang (Hakim, 2006). Pandangan Ricardian menerapkan logika konsumen dalam menilai pengaruh utang pemerintah terhadap perekonomian melalui variabel konsumsi masyarakat. Konsumen diasumsikan bersikap rasional dalam menanggapi kebijakan fiskal dan penarikan pinjaman/utang yang dilakukan oleh pemerintah. Konsumen memahami bahwa peningkatan utang pemerintah saat ini sebagai akibat dari kebijakan fiskal ekspansif akan menyebabkan pajak yang lebih tinggi di masa depan. Sehingga, konsumen yang mempunyai pandangan ke depan tidak menggunakan peningkatan pendapatan setelah pajak untuk keperluan pengeluaran konsumsi, tetapi ditabung dalam rangka membayar kewajiban pajak di masa yang akan datang. Implikasinya, kebijakan utang pemerintah seharusnya tidak menyebabkan konsumen meningkatkan pengeluarannya (Mankiw, 2008).

Hadiwibowo (2008) melakukan penelitian tentang Ricardian Equivalence Hypothesis (REH) di Indonesia yang hasilnya menunjukkan bahwa kebijakan fiskal, baik melalui instrumen pengeluaran pemerintah maupun pajak dan utang luar negeri pemerintah tidak mempengaruhi konsumsi masyarakat dalam jangka pendek. Berlakunya hipotesis Ricardian di sisi lain menegaskan bahwa teori Keynes tentang adanya pengaruh kebijakan pemerintah terutama dalam jangka pendek tidak dapat dibuktikan di Indonesia. Berdasarkan penelitian Hadiwibowo tersebut, masyarakat berpikir rasional sehingga tidak merespon kebijakan pemerintah dengan melakukan perubahan konsumsi. Hasil penelitian Hadiwibowo sesuai dengan kesimpulan Kormendi (1983) yang mendukung berlakunya hipotesis Ricardian. Beberapa penelitian lainnya tentang topik yang sama memberikan kesimpulan yang berbeda 
berupa penolakan terhadap hipotesis Ricardian. Marinheiro (2001) melakukan analisis terhadap REH dengan menggunakan konsumsi masyarakat sebagai variabel dependen dan variabel-variabel kebijakan fiskal, pendapatan dan kekayaan sebagai variabel independen. Salah satu model yang digunakan dapat ditulis ke dalam persamaan sebagai berikut:

$$
\begin{aligned}
& C_{t}=\alpha_{0}+\alpha_{1} G D P_{t}+\alpha_{2} G_{t}+\alpha_{3} W_{t}+ \\
& \alpha_{4} \text { TRANSFERS }_{t}+\alpha_{5} \text { TX }_{t}+\alpha_{6} \text { GINT }_{t}+ \\
& \alpha_{7} G B_{t}+u_{t}
\end{aligned}
$$

Di mana:

$\begin{array}{ll}\text { C } & \text { : Konsumsi masyarakat } \\ \text { GDP } & \text { : Gross Domestic Product } \\ \text { G } & : \text { Pengeluaran pemerintah } \\ \text { W } & : \text { Wealth/kekayaan } \\ \text { TRANSFERS } & \text { : Transfer pemerintah } \\ \text { kepada individu } & \end{array}$

$\begin{array}{ll}\text { TX } & : \text { Pajak } \\ \text { GINT } & : \text { Pembayaran bunga utang } \\ \text { GB } & : \text { Utang pemerintah }\end{array}$

Hasil dari penelitian tersebut menolak berlakunya REH untuk kasus perekonomian Portugis. Selanjutnya, penelitian Belingher dan Moroianu (2015) juga menunjukkan bahwa REH tidak berlaku di perekonomian Romania. Perbedaan hasil penelitian tentang berlaku atau tidaknya Ricardian Equivalence Hypothesis menjadi hal yang menarik untuk dilakukan analisis lebih lanjut, terutama berkaitan dengan bagaimana penerapannya di Indonesia.

Kebijakan fiskal dapat didefinisikan sebagai kebijakan yang dilakukan pemerintah melalui instrumen fiskal seperti pengeluaran pemerintah dan/atau pajak untuk mempengaruhi tingkat permintaan agregat perekonomian (Nanga, 2001).

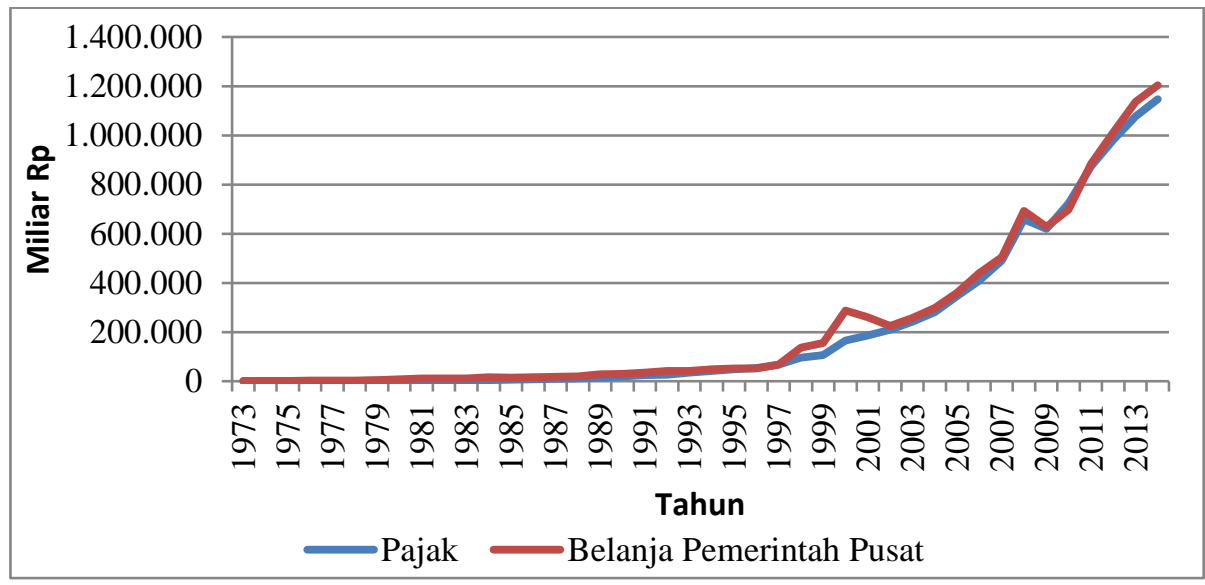

Grafik 3. Perkembangan Pajak dan Belanja Pemerintah Pusat Tahun 1973 - 2014

Sumber: Kementerian Keuangan, diolah.

Berdasarkan Grafik 3, perkembangan pajak dan belanja pemerintah pusat di dalam struktur APBN menunjukkan tren positif. Penurunan penerimaan pajak hanya terjadi satu kali selama periode 1973 hingga 2014, yaitu pada tahun 2009 dengan tingkat penurunan sebesar 5,89\%. Melalui reformasi UU Perpajakan, penerimaan pajak kembali mengalami peningkatan hingga beberapa tahun terakhir. Penerimaan pajak didominasi oleh penerimaan pajak dalam negeri, di mana pada tahun 2014 mencapai 96\% dari total penerimaan pajak. Di sisi lain, perkembangan belanja pemerintah pusat lebih berfluktuasi dibandingkan perkembangan pajak. Selama periode 1973 hingga 2014, belanja pemerintah pusat mengalami penurunan beberapa kali dengan rata-rata tingkat penurunan sebesar 9,64\%.

Penelitian ini bertujuan untuk menganalisis bagaimana pengaruh Gross Domestic Product (GDP), kekayaan, variabel-variabel kebijakan fiskal (belanja pemerintah pusat, pajak 
dan pembayaran bunga utang) serta utang luar negeri pemerintah terhadap konsumsi masyarakat. Variabel kekayaan dapat di-proxy dengan indikator agregat moneter atau jumlah uang beredar (Darby et al. dalam Hadiwibowo, 2008) (variabel kekayaan di dalam penelitian ini di-proxy dengan jumlah uang beredar dalam arti luas).

\section{METODE PENELITIAN}

Data yang digunakan dalam penelitian ini merupakan data sekunder, diperoleh dari Direktorat Jenderal Perbendaharaan Negara (DJPBN) Kementerian Keuangan, Badan Pusat Statistik (BPS) dan World Bank. Periode data yang digunakan adalah tahunan, dari tahun 1973 hingga tahun 2014. Tahun fiskal Anggaran Pendapatan dan Belanja Negara (APBN) disesuaikan menjadi 1 Januari hingga 31 Desember untuk semua tahun anggaran.

Model dasar dalam penelitian ini mengacu pada model yang digunakan oleh Kormendi (1983) dan Hadiwibowo (2008) dalam meneliti pengaruh variabel kebijakan fiskal dan utang luar negeri pemerintah terhadap konsumsi masyarakat. Metode analisis yang digunakan adalah Error Correction Model (ECM). ECM pertama kali dikembangkan oleh Sargan yang kemudian dipopulerkan oleh Engle dan Granger untuk mengoreksi keadaan ketidakseimbangan (disequilibrium). Teori Representasi Granger menjelaskan bahwa ketika dua variabel atau lebih berkointegrasi, maka hubungan antar variabel tersebut dapat dinyatakan sebagai ECM (Gujarati dan Porter, 2013). Persamaan dasar dalam penelitian ini yaitu:
$\mathrm{PC}=\mathrm{f}(\mathrm{GDP}, \mathrm{GS}, \mathrm{W}, \mathrm{TX}, \mathrm{GINT}, \mathrm{GFD})$

Persamaan (2) dapat dituliskan ke dalam model ekonometrik sebagai berikut:

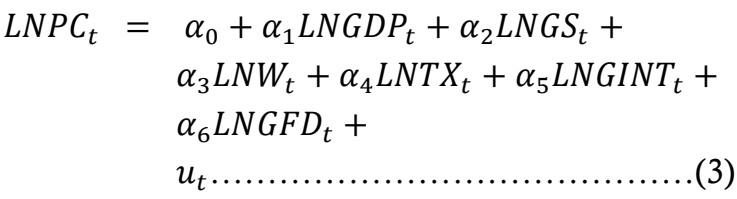

Selanjutnya, persamaan (3) dapat diturunkan menjadi persamaan ECM sebagai berikut:

$$
\begin{aligned}
\Delta L N P C_{t}= & \beta_{0}+\beta_{1} \Delta L N G D P_{t}+\beta_{2} \Delta L N G S_{t}+ \\
& \beta_{3} \Delta L N W_{t}+\beta_{4} \Delta L N T X_{t}+\beta_{5} \Delta L N G I N T_{t}+ \\
& \beta_{6} \Delta L N G F D_{t}+\beta_{7} u_{t-1}+\varepsilon_{t} \ldots \ldots \ldots \ldots \ldots . .(4)
\end{aligned}
$$

Dimana:

PC : Konsumsi masyarakat

GDP : Pendapatan domestik bruto

GS : Belanja pemerintah pusat

W : Kekayaan

TX : Total penerimaan pajak

GINT : Pembayaran bunga utang

GFD : Utang luar negeri pemerintah

\section{HASIL DAN PEMBAHASAN}

Tahap pertama yang harus dilakukan dalam melakukan estimasi dengan menggunakan data runtun waktu (time series) adalah mengetahui apakah data tersebut stasioner atau tidak. Hal ini penting untuk menghindari terjadinya fenomena dari spurious (phenomenom of spurious) atau regresi tanpa memiliki arti (nonsense regression). Berikut merupakan hasil uji unit root data time series yang digunakan di dalam penelitian:

Tabel 1. Hasil Uji Unit Root Phillips-Perron

\begin{tabular}{lll}
\hline \multicolumn{1}{c}{ Variabel } & \multicolumn{2}{l}{ Philips-Perron Statistic } \\
\cline { 2 - 3 } & Tingkat Level & Tingkat First Difference \\
\hline LNPC & $-2,327994$ & $-4,964707^{*}$ \\
LNGDP & $-2,081361$ & $-4,594060^{*}$ \\
LNGS & $-3,925953^{* *}$ & $-7,321449^{*}$ \\
LNW & $-0,816455$ & $-5,195562^{*}$ \\
LNTX & $-1,098694$ & $-7,864565^{*}$ \\
LNGINT & $-1,491784$ & $-7,039146^{*}$ \\
LNGFD & $-2,810488$ & $-4,760878^{*}$ \\
\hline
\end{tabular}

Keterangan: * dan ${ }^{* *}$ masing-masing signifikan pada level $1 \%$ dan $5 \%$

Sumber: Hasil Olahan Penulis (2016) 
Berdasarkan Tabel 1, variabel konsumsi masyarakat, GDP, kekayaan, pajak, pembayaran bunga utang dan utang luar negeri pemerintah tidak stasioner pada tingkat level. Hanya variabel belanja pemerintah pusat yang signifikan pada tingkat level dengan $\propto 5 \%$. Pengujian kemudian dilakukan pada tingkat first difference untuk mengetahui stasioneritas data. Hasil uji unit root menunjukkan bahwa semua variabel telah stasioner pada first difference dengan menggunakan $\propto 5 \%$.

Kointegrasi menunjukkan adanya hubungan jangka panjang atau keseimbangan antar variabel yang digunakan di dalam penelitian. Uji kointegrasi dilakukan terhadap residual, yang hasilnya disajikan dalam Tabel 2 sebagai berikut:

Tabel 2. Hasil Uji Kointegrasi Variabel Dependen: D(RESID01)

\begin{tabular}{llll}
\hline Variabel & Koefisien & t-statistic & Prob. \\
\hline RESID01(-1) & $-0,850941$ & $-5,568912$ & $0,0000^{*}$ \\
\hline Keterangan: * signifikan pada level 5\% & & \\
Sumber: Hasil Olahan Penulis (2016) & &
\end{tabular}

Berdasarkan hasil uji kointegrasi, nilai probabilitas lebih kecil daripada tingkat signifikansi $\propto 5 \%$, sehingga dapat disimpulkan bahwa residual bersifat stasioner atau dapat dikatakan terdapat hubungan kointegrasi atau keseimbangan jangka panjang antar variabel di dalam model penelitian. Uji asumsi klasik diperlukan untuk memastikan bahwa estimator yang dihasilkan adalah terbaik dan tidak bias (Best Linear Unbiased Estimator). Terdapat tiga pengujian asumsi yang digunakan di dalam penelitian ini, yaitu uji normalitas, uji autokorelasi, dan uji multikolinearitas. Berdasarkan hasil pengujian normalitas diketahui bahwa nilai probabilitas JB-statistic sebesar 0,830866 (lebih besar daripada tingkat signifikansi $\propto 5 \%)$. Selanjutnya, pendeteksian autokorelasi dengan menggunakan uji Breusch-Godfrey (BG) menghasilkan nilai probabilitas chi-square sebesar 0,1406 (lebih besar daripada tingkat signifikansi $\propto$ $5 \%)$ serta hasil pengujian multikolinearitas dengan menggunakan Variance Inflation Factor (VIF) menunjukkan bahwa tidak terdapat variabel yang nilai VIF-nya lebih dari 10 . Berdasarkan ketiga hasil pengujian tersebut dapat disimpulkan bahwa tidak ada pelanggaran asumsi klasik di dalam model penelitian.

Uji kecocokan model (goodness of fit) dilakukan dengan menghitung koefisien determinasi atau $\mathrm{R}^{2}$. Berdasarkan hasil estimasi persamaan Error Correction Model (ECM), nilai $\mathrm{R}^{2}$ sebesar 0,7407 . Artinya, variasi perubahan variabel konsumsi masyarakat dalam jangka pendek mampu dijelaskan sebesar $74,07 \%$ oleh variasi perubahan variabel GDP, belanja pemerintah pusat, kekayaan, pajak, pembayaran bunga utang dan utang luar negeri pemerintah. Kemampuan variabel independen untuk menjelaskan variasi perubahan konsumsi masyarakat dalam jangka panjang lebih besar $\left(\mathrm{R}^{2}\right.$ hasil estimasi persamaan kointegrasi mencapai 99,85\%) dibandingkan kemampuannya menjelaskan variasi perubahan konsumsi dalam jangka pendek melalui ECM.

Uji $\mathrm{F}$ digunakan untuk melihat pengaruh variabel GDP, belanja pemerintah pusat, kekayaan, pajak, pembayaran bunga utang dan utang luar negeri pemerintah terhadap variabel kosumsi masyarakat secara simultan/serempak. Nilai F-tabel untuk persamaan ECM dan persamaan kointegrasi masing-masing sebesar 2,33 dan 2,42. Nilai F-statistic yang diperoleh dari hasil estimasi yaitu 13,47 dan 3859,62 . Nilai tersebut lebih besar daripada nilai F-tabel 2,33 dan 2,42, sehingga dapat disimpulkan bahwa variabelvariabel independen yang digunakan di dalam penelitian ini secara simultan berpengaruh signifikan terhadap variabel dependen konsumsi masyarakat, baik dalam jangka pendek maupun jangka panjang. Selanjutnya, uji t digunakan untuk melihat pengaruh variabel GDP, belanja pemerintah pusat, kekayaan, pajak, pembayaran bunga utang dan utang luar negeri pemerintah terhadap variabel kosumsi masyarakat secara parsial /individual. Tabel 3 dan Tabel 4 berikut ini merupakan nilai t-statistic masing-masing variabel 
yang diperoleh dari hasil estimasi serta menunjukkan pengambilan keputusan pengaruh variabel independen secara parsial:

Tabel 3. Nilai t-statistic Persamaan ECM (Jangka Pendek)

\begin{tabular}{lll}
\hline Variabel & t-statistic & Keterangan \\
\hline DLNGDP & 7,018 & Signifikan \\
DLNGS & 1,433 & $\begin{array}{l}\text { Tidak } \\
\text { signifikan }\end{array}$ \\
DLNW & 3,912 & Signifikan \\
DLNTX & $-3,004$ & Signifikan \\
DLNGINT & 0,474 & Tidak \\
& & Signifikan \\
DLNGFD & $-1,787$ & Signifikan \\
RESID01(-1) & $-3,436$ & Signifikan \\
\hline
\end{tabular}

Sumber: Hasil Olahan Penulis (2016)

Persamaan jangka panjang hasil estimasi:

$$
\begin{aligned}
& L_{N P C_{t}=}=1,415+0,893 L N G D P_{t}+ \\
& 0,093 L N G S_{t}+0,213 L N W_{t}- \\
& 0,246 L N T X_{t}+0,042 L N G I N T_{t}- \\
& 0,170 L N G F D_{t} \ldots \ldots \ldots \ldots \ldots \ldots(5)
\end{aligned}
$$

Persamaan jangka pendek hasil estimasi:

$$
\begin{aligned}
& \Delta L N P C_{t}=\quad 0,005+0,759 \Delta L N G D P_{t}+ \\
& 0,032 \Delta L N G S_{t}+0,195 \Delta L N W_{t}- \\
& 0,152 \Delta L N T X_{t}+ \\
& 0,006 \Delta L N G I N T_{t}- \\
& 0,081 \Delta L N G F D_{t}-0,535 u_{t-1} . .(6)
\end{aligned}
$$

Error Correction Model (ECM) dapat dikatakan valid apabila koefisien dari Error Correction Term (ECT) bernilai negatif dan signifikan (Gujarati dan Porter, 2013). Koefisien ECT dari hasil estimasi bernilai -0,535 dan signifikan pada $\propto 5 \%$, sehingga ECM yang digunakan dalam penelitian ini merupakan model yang valid. Koefisien $-0,535$ dapat diartikan bahwa perbedaan sebesar 53,5\% antara jangka panjang dan jangka pendek bisa dikoreksi dalam satu periode.

Variabel pendapatan domestik bruto (GDP) berpengaruh positif signifikan terhadap konsumsi masyarakat dalam jangka pendek dan jangka panjang. Kenaikan GDP sebesar 1\% akan meningkatkan konsumsi sebesar 0,759\% dalam jangka pendek, sedangkan dalam jangka panjang kenaikan GDP sebesar 1\% akan meningkatkan konsumsi sebesar 0,893\%. Koefisien perubahan konsumsi akibat perubahan GDP lebih besar daripada koefisien perubahan konsumsi akibat perubahan variabel independen lainnya. Hal ini sejalan dengan teori konsumsi bahwa pendapatan merupakan faktor utama yang mempengaruhi pengeluaran konsumsi. Hasil ini juga mendukung penelitian Marinheiro (2001) serta Belingher dan Moroianu (2015) bahwa pendapatan berpengaruh positif signifikan terhadap konsumsi.

Variabel belanja pemerintah pusat dan pembayaran bunga utang tidak signifikan mempengaruhi konsumsi masyarakat dalam jangka pendek. Tidak signifikannya variabelvariabel tersebut dalam mempengaruhi konsumsi sejalan dengan hasil penelitian Marinheiro (2001) dengan menggunakan ECM. Masyarakat tidak merespon kebijakan pengeluaran pemerintah dengan melakukan perubahan konsumsi. Hal ini sesuai dengan hipotesis Ricardian bahwa pengeluaran pemerintah tidak memberikan pengaruh yang signifikan bagi perekonomian.

Tabel 4. Nilai t-statistic Persamaan Kointegrasi (Jangka Panjang)

\begin{tabular}{lll}
\hline Variabel & t-statistic & Keterangan \\
\hline LNGDP & 9,722 & Signifikan \\
LNGS & 4,916 & Signifikan \\
LNW & 6,360 & Signifikan \\
LNTX & $-7,477$ & Signifikan \\
LNGINT & 3,119 & Signifikan \\
LNGFD & $-4,579$ & Signifikan \\
\hline
\end{tabular}

Sumber: Hasil Olahan Penulis (2016)

Akan tetapi, dalam jangka panjang kedua variabel tersebut berpengaruh secara signifikan terhadap perubahan konsumsi masyarakat. Variabel pembayaran bunga utang dan belanja pemerintah pusat mempunyai arah pengaruh yang positif. Kenaikan pembayaran bunga utang dan belanja pemerintah pusat sebesar $1 \%$ masingmasing akan meningkatkan konsumsi sebesar 
$0,042 \%$ dan $0,093 \%$. Komposisi pembayaran bunga utang pemerintah di dalam Anggaran Pendapatan dan Belanja Negara (APBN) didominasi oleh pembayaran bunga utang dalam negeri. Ketika pemerintah melakukan pembayaran beban bunga, maka akan ada tambahan pendapatan yang diterima penduduk, sehingga hal ini akan berdampak positif pada perubahan konsumsi agregat. Inilah mengapa variabel pembayaran bunga utang di dalam penelitian berpengaruh positif terhadap konsumsi.

Selanjutnya, variabel belanja pemerintah pusat berpengaruh positif signifikan terhadap konsumsi. Komposisi belanja pemerintah pusat di dalam APBN didominasi oleh belanja subsidi, di mana jenis belanja ini bersifat komplemen/melengkapi pengeluaran konsumsi masyarakat. Belanja pemerintah yang semakin tinggi akan mendorong peningkatan pengeluaran masyarakat, atau dengan kata lain akan meningkatkan konsumsi agregat di dalam suatu perekonomian.

Variabel kekayaan (W) mempunyai arah pengaruh yang sama dengan variabel Gross Domestic Product dan signifikan secara statistik dalam mempengaruhi perubahan konsumsi masyarakat dalam jangka pendek dan jangka panjang. Kenaikan kekayaan sebesar 1\% akan meningkatkan konsumsi sebesar 0,195\% dalam jangka pendek, sedangkan dalam jangka panjang kenaikan kekayaan sebesar $1 \%$ akan meningkatkan konsumsi sebesar 0,213\%. Menurut Sukirno (2013), rumah tangga dengan kekayaan yang mencukupi tidak akan terdorong untuk menabung lebih banyak, sehingga pendapatan yang digunakan untuk konsumsi di masa sekarang akan semakin besar. Dengan demikian, tingkat kekayaan yang semakin tinggi akan mendorong rumah tangga untuk semakin memperbesar konsumsi.

Penerimaan pajak berpengaruh negatif signifikan terhadap konsumsi dalam jangka pendek dan jangka panjang. Peningkatan pajak sebesar $1 \%$ akan menurunkan konsumsi masyarakat sebesar $0,152 \%$ dalam jangka pendek, sedangkan dalam jangka panjang peningkatan pajak sebesar $1 \%$ akan menurunkan konsumsi masyarakat sebesar $0,246 \%$.
Hal ini sesuai dengan teori yang dikemukakan oleh Keynes bahwa pajak yang dipungut oleh pemerintah dapat mengurangi pendapatan yang siap dibelanjakan, sehingga akan menurunkan konsumsi.

Variabel utang luar negeri pemerintah mempengaruhi konsumsi masyarakat secara negatif dan signifikan dalam jangka pendek dan jangka panjang. Peningkatan utang luar negeri pemerintah sebesar $1 \%$ akan menurunkan konsumsi masyarakat sebesar $0,081 \%$ dalam jangka pendek, sedangkan dalam jangka panjang peningkatan utang luar negeri pemerintah sebesar $1 \%$ akan menurunkan konsumsi masyarakat sebesar $0,170 \%$. Hasil penelitian ini menolak hipotesis Ricardian bahwa utang luar negeri bersifat netral atau tidak mempengaruhi kondisi perekonomian. Hasil penelitian menunjukkan bahwa utang luar negeri berpengaruh signifikan terhadap konsumsi, namun tanda koefisien yang negatif juga tidak sesuai dengan teori Keynes bahwa utang luar negeri seharusnya memberikan dampak positif bagi perekonomian, yang juga akan berdampak positif pada peningkatan konsumsi agregat. Hal ini bisa mengindikasikan bahwa terdapat ketidakefektifan penggunaan utang luar negeri, di mana utang yang seharusnya dapat dimanfaatkan untuk mampu meningkatkan perekonomian justru menjadi perangkap yang bebannya semakin tahun semakin mengalami peningkatan.

Konsekuensi dari penarikan utang luar negeri adalah pemerintah harus membayar kembali jumlah utang. Langkah yang dilakukan pemerintah untuk menutupi pembayaran utang yaitu dengan melakukan pemungutan pajak. Pajak yang lebih tinggi akan mengurangi pendapatan masyarakat siap dibelanjakan, sehingga hal ini juga akan berdampak pada penurunan tingkat konsumsi agregat. Hal ini sejalan dengan pendapat yang dikemukakan oleh Todaro (dalam Djamin, 1995) bahwa bantuan/utang luar negeri yang diberikan kepada negara berkembang tidak akan meningkatkan pertumbuhan lebih cepat, tetapi justru memundurkan perekonomiannya. Bahkan, ada negara berkembang yang terlilit 
utang luar negeri akibat beratnya persyaratan bantuan/utang luar negeri tersebut.

\section{SIMPULAN}

Dukungan atas hipotesis Ricardian melalui Error Correction Model (ECM) hanya dapat diamati melalui netralitas belanja pemerintah pusat dan pembayaran bunga utang, sedangkan variabel utang luar negeri pemerintah dan kebijakan fiskal melalui instrumen pajak tidak menunjukkan hal yang sama. Bahkan, variabel-variabel tersebut dalam jangka panjang justru berpengaruh signifikan terhadap perubahan konsumsi. Secara keseluruhan, penelitian ini tidak mendukung berlakunya Ricardian Equivalence Hypothesis (REH) di Indonesia untuk periode 1973 hingga 2014.

Penelitian ini menggunakan Error Correction Model (ECM) untuk mengamati perilaku jangka pendek variabel GDP, belanja pemerintah pusat, kekayaan, pajak, pembayaran bunga utang dan utang luar negeri pemerintah dalam mempengaruhi konsumsi masyarakat. Keterbatasan dari penggunaan ECM yaitu tidak bisa mengetahui berapa jangka waktu (tahun) yang dibutuhkan untuk bisa mengkategorikan suatu periode ke dalam jangka pendek atau jangka panjang. Selain itu, variabel kebijakan fiskal melalui instrumen belanja pemerintah yang digunakan di dalam penelitian ini merupakan belanja pemerintah pusat, tidak memperhitungkan besarnya belanja pemerintah tingkat daerah sebagai faktor yang juga mempengaruhi keputusan konsumsi.

\section{DAFTAR PUSTAKA}

Badan Pusat Statistik. http://www.bps.go.id Belingher, Daniel dan Nicolae Moroianu. 2015. "Empirical Evidence on the Ricardian Equivalence in Romania." Journal of Theoretical and Applied Economics. Volume XXII, No. 2. Page $163-170$.

Direktorat Jenderal Perbendaharaan Negara, Kementerian Keuangan Republik Indonesia. http://www.djpbn.kemenkeu.go.id

Djamin, Zulkarnain. 1995. Sumber Luar Negeri bagi Pembangunan Indonesia. Jakarta: Penerbit Universitas Indonesia (UI-Press).
Ghozali, Imam dan Dwi Ratmono. 2013. Analisis Multivariat dan Ekonometrika: Teori, Konsep dan Aplikasi dengan EViews 8. Semarang: Badan Penerbit Universitas Diponegoro.

Gujarati, Damodar N. dan Dawn C. Porter. 2013. Dasar-dasar Ekonometrika. Edisi 5 Buku 2. (Terj.) Raden Carlos Mangunsong. Jakarta: Salemba Empat.

Hadiwibowo, Yuniarto. 2008. "Ricardian Equivalence in Developing Countries: Fiscal Policy, Private Consumption and Investment in Indonesia." Conference Paper disajikan pada $11^{\text {th }}$ International Convention of the East Asian Economic Association. Manila. 15 - 16 November 2008.

Hakim, Lukman. 2006. "Pengaruh Utang Luar Negeri, Kebijakan Fiskal terhadap Konsumsi Masyarakat dalam Paradigma Ricardian Equivalence 1990 - 2004: Penerapan Model Vector Auto Regressions (VAR)," dalam Jurnal Ekonomi Pembangunan. Vol. 11, No. 2. Hal: 125 - 145 .

Kementerian Keuangan. 2011. "Penyusunan Model Efisiensi Belanja Negara terhadap Pertumbuhan Ekonomi, Tingkat Kemiskinan dan Pengangguran." http://kemenkeu.go.id

Kormendi, Roger C. 1983. "Government Debt, Government Spending and Private Sector Behavior." The American Economic Review. Vol. 73, No.5.

Mankiw, N. Gregory. 2008. Makroekonomi. Edisi Keenam. (Terj.) Fitria Liza dan Imam Nurmawan. Jakarta: Erlangga.

Marinheiro, Carlos Fonseca. 2001. "Ricardian Equivalence: an Empirical Application to the Portuguese Economy." Faculty of Economics of the University of Coimbra and Katholieke Universiteit Leuven.

Mason, Robert D. dan Douglas A. Lind. 1999. Teknik Statistika untuk Bisnis dan Ekonomi. Edisi 9 Jilid 2. (Terj.) Widyono Soetjipto dkk. Jakarta: Erlangga.

Nanga, Muana. 2001. Makroekonomi: Teori, Masalah dan Kebijakan. Jakarta: PT RajaGrafindo Persada.

Sukirno, Sadono. 2013. Makroekonomi: Teori Pengantar. Edisi Ketiga. Jakarta: Rajawali Pers.

World Bank. http://www.worldbank.org. 